\title{
Introduction
}

\section{Public Sector Reforms and the Quest for Democratic Developmentalism in Africa}

\author{
Omano Edigheji*
}

\begin{abstract}
Developmentalism has been one of the main justifications for public sector reforms. In what concerns Africa, this, in part, has been based on the assumption that public sector reforms, which will make the state effective, efficient, responsive, accountable and productive, are necessary conditions for the development of the continent. Not surprisingly, a plethora of public sector reforms has been initiated and implemented. The intersection, synergies, complementarities and, at times, disjunctures between the reforms and the continent's quest for development, may not have received the scholarly attention it deserved, beside a few exceptions, including the work of the late Professor Guy Mhone. Therefore, this introductory article will focus on the public sector reforms in Africa, especially as from the 1980s, and will necessarily draw heavily on the work of Guy Mhone.
\end{abstract}

\section{Résumé}

Le développementalisme a été l'une des principales justifications de la réforme du secteur public. En ce qui concerne l'Afrique, cela a été en partie fondée sur l'hypothèse selon laquelle les réformes du secteur public, qui rendront l'État efficace, efficient, dynamique, responsable et productif, sont des conditions nécessaires pour le développement du continent. Sans surprise, une pléthore de réformes du secteur public a été initiée et mise en œuvre. L’intersection, les énergies, les complémentarités et parfois la disjonction entre les réformes et la quête de développement du continent, n’ont pas vraiment reçu l'attention méritée au niveau universitaire, à part quelques exceptions comme l'œuvre du professeur Guy Mhone. Par conséquent, cet article introductif mettra l'accent sur les réformes du secteur public en Afrique, en particulier dès les années 1980 et s’inspirera fortement des travaux de Guy Mhone.

* Research Director, Policy Analysis Unit/Centre for Africa’s Social Progress, Human Sciences Research Council, South Africa, E-mail: oedigheji@hsrc.ac.za. 


\section{Background: The Social, Economic and Political Contexts of Public Sector Reforms in Africa}

Guy Mhone rightly argued that "issues related to public sector and civil service reform should be located in a broader framework that addresses the nexus of the problems related to governance and democratization and sustainable development” (Mhone 2003a:19). Any critical analysis of the public sector reforms in Africa must therefore focus on how it addresses the key social, economic and political challenges facing the continent.

The development and governance deficits of Africa are generally acknowledged by academics and policy practitioners. Bad governance, authoritarianism, one-party rule and military dictatorship have been some of the major features of Africa's politics. Its economy remained primary sector based. Majority of its people are overwhelmed by poverty and have no access to basic services. Guy Mhone's understanding of the underdevelopment of Africa is encapsulated in his concepts of enclavity and dualism of the continent's economies (Mhone 2000). The enclave nature of Africa has meant that majority of the African people are excluded from the formal economy. One reason for this development is that "the majority of the labour force in Africa continues ... to be unemployed and underemployed" (Mhone 2000:1). While various reforms - including the Brettonwood institutions-inspired structural adjustment programmes (SAPs) and the good governance project largely inspired by international development agencies and donor countries; social, economic and political reforms - were undertaken in the 20th century, they did not resolve the Africa's development and democratic deficits.

Hence, at the turn of the 21st century, Africa remains the poorest region in the world. Compared to other continents, Africa has the lowest tele-density and internet connectivity, the highest rate of people living below the poverty line (by 2002, 44 per cent of the people in sub-Saharan Africa live below the poverty level of $\$ 1$ dollar a day), the highest rate of HIV-AIDS infections, the highest rate of infant mortality and maternal death rates, the highest level of unemployment and the lowest rate of access to basic services. Therefore, if this trend continues, Africa is likely to miss out on the information revolution, just as it missed out on the industrial revolution and there will be increased widening gap between Africa and the rest of the world. Also, Africa, especially sub-Saharan Africa, is unlikely to meet the Millennium Development Goals (MDGs) of halving extreme poverty, halting the spread of HIV/AIDS and providing universal primary education by 2015 .

At the political level, the 20th century was marked by the de-colonialisation struggle, political independence, one-party rule, military dictatorship and the subsequent wave of multi-party democracy in the 1990s. In spite of this 
positive development - that is, the spread of multi-partyism - the majority of the African people have been largely excluded from the process of governance. In particular, across the continent (like other regions of the world), citizen power has been substituted with elite and corporate power. One of the consequences of this development is that citizen democracy is being replaced by consumer, client and user democracy; and in the context of high rate of unemployment and poverty, the majority of African people have become marginal to the process of development and governance. At best, their role is limited to voting for office bearers. Even this role is being undermined by the incessant rigging of elections that has characterised political life in most African countries. As a result, most governments in the continent lack legitimacy, and therefore suffer credibility problem.

What this brings to light is that while liberal democracy is necessary, it is not a sufficient condition for democratic development. As Mhone (2003b:19) notes, "the conventional understanding of democracy as currently pursued...coupled with economic liberalism as the dominant approach to economic and social policy, is at odds with the need to promote sustainable human development and good governance, and hence is ultimately detrimental to the consolidation of both formal (procedural and representative) and substantive (or emancipatory) democracy in the long run”. Democratic development and governance will require popular/citizens participation, which in turn requires economic base. By this we mean that, for the African people to effectively participate in the governance and development process, they require more economic assets. In other words, more economic assets in the hands of the poor in Africa as elsewhere, is a sine qua non for their democratic participation and, consequently, the sustainability of democratic governance.

Mhone (2003b:41) argues that "in order to precipitate developmental momentum, redistributive measures are needed" as though they may not necessarily be compatible with procedural democracy, they are compatible with developmental democracy. The key question therefore is how do the public sector reforms address these apparent tensions? Answering the question is to address how to democratize the politics and economies to give ordinary people greater say, not only in the determination of their own affairs, but also in the process of governance at all levels - community, local, state/provincial and national levels. This is one of the benchmarks that Mhone sets for us in assessing the public sector reforms in the continent.

It is important to note, at this juncture, that Africa has been a laboratory for a number of social and economic reforms. In the first decade of political independence - that is, from the early 1960s until the mid-1970s - the emergent African political leaders attempted to provide basic services to majority of the people. Towards this end, a number of public utilities were established, 
which considerably enhanced the capacity of the African state to provide basic social services to the African people. At the same time, the SOEs were the institutional foundation for import substitution industrialization in Africa. The state was seen as central to the process of socio-economic engineering that the newly independent countries required, hence the establishment of the SOEs, among a range of institutional innovations intended to enhance the capacity of the state. This background is important because the privatization exercise that constitutes a central element of the public sector reforms as from the 1980s strikes at the heart of hallowing out the state in Africa and its ability to provide public goods to the African people.

The prevailing development paradigm, up to the late 1970s, emphasized equity, social justice and improvement of the material conditions of people, with the state occupying a prime place in the development process. In other words, developmentalism was one of the main underpinnings of Africa in its first decade of independence. Mhone defined developmentalism "as a conscious, strategic stance taken by government to promote accelerated growth, structural transformation, social development and the repositioning of the economy in the international division of labour by consciously influencing the performance of the market” (Mhone 2003:39). Such an approach that places the majority of people at the centre of development, argues Mhone, has to be "rooted in participatory and consultative approaches to policy making and implementation". Unfortunately, the majority of Africa's people and their organisations were excluded from the governance process, as the state became captured by special interests and a basis for primitive accumulation by political leaders and state officials. In this context, public policies were made without regard to economic logics, human well-being and democratic governance. In particular, governance and public policy were, and remained, dominated by professional politicians and consultants. More disturbing is that the public sector reforms have been driven in technocratic fashion, with limited inputs from citizens. The non-state actors that are incorporated are middle class-run civil society organisations, most of which are not embedded in any community. In this context, peoples' organisation, namely community/grassroots groups have been excluded from the process of governance and development. This is one of the major deficits of Africa in the new millennium. Whether the public sector reforms introduced in the last thirty years or so have addressed this issue effectively remains to be seen.

At the beginning of 21st century, there was again a paradigm shift, especially following the failure of policies of market fundamentalism and the ever-widening gap between the poor and the rich, and between developing and developed countries, as well as increasing poverty. This, even in the context of modest growth experienced by Africa since the mid-1990s, has 
not benefited majority of its people. In fact, it has reinforced and accentuated the enclave and dualistic nature of African economies. While this growth pattern has been beneficial to the enclave formal sector, it has been unable to engender inclusive and equitable growth. As a result, argues Mhone (2000), it has accentuated the structural limits of African economies by, among other things, excluding and marginalizing the majority of the continent populace from engaging in productive and income generating activities that could result in sustainable increases in their living standard. It is in the light of this that some might consider a public sector reform agenda that aimed primarily to promote a narrow vision of development, and where efficiency and effectiveness is judged mainly by contribution to quantitative growth, as deficient.

In Africa, as in other regions, there is a recognition that the socio-economic climate is not sustainable in the long-run - as the recent global economic meltdown reinforces the correctness of the need for a need approach. The paradigm shift in development thinking is evidenced by the adoption of the MDGs by the UN and the New Partnership for Africa Development (NEPAD). These are complemented by the Constitutive Act of the African Union (AU). Significantly, both the NEPAD and AU objectives are cognizant of the fact that good governance, peace and security are necessary conditions for development. While political leaders have committed themselves to these goals and objectives, these have not been domesticated, that is, translated into national policy. As such, national social, economic and political policies remained largely at odds with the goals of the NEPAD and AU Constitutive Act. More importantly, the shift in paradigm may in the long run fundamentally alter the pattern of accumulation, as the formal sector continues to be seen as the basis for growth. This is likely to resolve the duality of the African economies in a manner that assets in the informal sector are harnessed to propel growth and economically empower the majority of the African population. A key question that should therefore agitate the minds of critical observers of Africa is, what are the factors that accounted for the disjuncture between goals of NEPAD and national policies and praxis? And what has been the role of the donors-driven public sector reforms in alleviating or accentuating this problem? Another critical question that demands attention is, what has been the contribution of the public sector reforms in hampering or enhancing the continent's ability to harness the assets in the informal economy so that it can become the engine of inclusive and equitable development. The contributions of the public sector reforms to address these critical issues, I argue, are important benchmarks to judge the effectiveness or otherwise of the public sector reforms. 
It needs to be noted that, by the second half of the 1970s, the development and nation-building projects of Africa had ruptured, due to both internal and external factors. Importantly, this period witnessed a global shift in development paradigm. Development came to be conceived narrowly in terms of economic growth, and the public sector reforms implemented since the 1980s are primarily geared towards this narrow concern; and effectiveness and efficiency became judged and assessed in terms of contribution to growth. Mkandawire (2008) points out that the reform agenda gives premium to "restraining" institutions rather than "transformative" institutions. In fact, the paradigm focused exclusively on short-term macro-economic stabilization, with little concern for issues of long-term growth and equity. The grand normative of the public reforms has therefore been economic growth, underpinned by a philosophical base of what Paul Omoyefa, in his contribution to this edition, refers to as the re-colonialization of Africa. Getting the economic fundamental rights and macroeconomic stabilization became the dominant thrusts of public policy. Needless to say that both state-led development and market-led development - the latter which continued to dominate public policy at the turn of the 21st century - have the same outcomes, namely the underdevelopment of Africa and its marginalization in the global political economy. However, in Africa as elsewhere, the 21st much more emphasis, at least at the level of discourse, is given to human well-being. And the current global economic meltdown - the worst since the great depression in the late 1920s - have brought into sharp focus the need for an inclusive development, and for the state to play active role in the development process. Clearly, the poor in Africa and elsewhere deserves a bigger bailout than the financial sector - if socialism is good for the banks, it will be better for the poor. A strong and active public sector in particular, and the state in general, is therefore necessary for the provision of public goods to majority of the African people. What is clear from the current economic crisis is that it has come to disrupt the paradigms within which the public sector reforms in Africa since the 1980s is predicated. A new paradigm that emphasizes an active public sector that promotes inclusive development is therefore urgently required.

A key challenge now is how to promote democratic governance and sustainable human development. As Guy Mhone (2003:18) puts it, "the question arises as to the degree which the...democratic dispensation and economic and social policies emanating from it can be consolidated and made sustainable in the long term”. It is against this background that we need to assess the public sector reforms that have been implemented across the African continent as from the 1980s, the focus of this special issue of Africa Development. 
The reforms are predicated on what is generally referred to as the New Public Management (NPM). As I note in a forthcoming article, NPM refers to a practice whereby the public sector is shaped and driven by private sector ethos, and it is run along corporate sector techniques. Cost effectiveness and efficiency become the dominant considerations for how the state is run. Components of the NPM include management decentralization within the public service, downsizing and right-sizing, outsourcing of government services, commodification, public-private partnerships, performance based contract for civil servants, granting of greater autonomy to state managers, especially those that run SOEs, and establishment of autonomous agencies - some of which were made to compete among themselves - within the state. NPM also entails devolution of budgets and financial control and the rise in the use of market competition in the provision of public services as well as increasing focus on efficiency, outputs and customer orientation (Edigheji, forthcoming). Other key elements of the NPM are commercialization, decentralization and privatization. These concepts are defined in some of the articles in this volume of Africa Development.

The reforms are generally cast in technical terms without regard to their broad implications. It needs to be noted that the public sector reforms informed by the NPM have broader implications for our body politics, governance and development. I have argued elsewhere that the reforms recast the relationship between citizens and the state. Instead of the state being responsive to citizens, the reforms promote an agenda that makes the state responsive only to users, clients and consumers (Edigheji, forthcoming). This has broader implications for the concept of citizenship and the nature and character between citizens and the state. The concept of public goods and its beneficiaries are also recast. Public goods now means provision of goods to make the market function efficiency, and access to services (which is monetized), dependent on ability to pay. Public sector institutions have become much more profit oriented. As a result, even when governments articulate a progressive agenda, the agenda of state-owned enterprises are at discord with a developmentalist agenda. One unfortunate outcome of the public sector reforms is that inclusive development has become elusive in the continent; and so, in general, the reforms have worsened inequality in the continent.

\section{Structure of the Journal}

In the discussion of public sector reforms in Africa, scholars and development agencies tend to treat the reforms in technical terms. However, Mhone (2003:19), calls for the interogation of their philosophical and normative underpinnings. It is to the former that Paul Omoyefa dedicates his article. 
Paul Omoyefa's main argument is that African leaders do not understand the philosophical basis of public reforms, which, according to him, are such that they enable western powers to encourage African leaders to generate enough funds to pay off the external debts. Omoyefa therefore concludes that these reforms are foisted by the western world on Africa.

The cognizance of the dictatorship of the donor community and the consequent lack of African ownership of some of the key reform agendas, including the public sector reforms, led to the Paris Declaration of 2005 as a new aid architecture for Africa. This is the subject of Lennart Wohlgemuth's article. The principles of the declaration require that Africa takes more responsibility for its development; aid should facilitate African ownership; donors should be aiding not dominating; donors should align their programmes to that of Africa's governments; and there should be mutual accountability between donors and the African state. Wohlgemuth expresses optimism about this new aid architecture. While this optimism might be well placed, a question that remains unanswered is whether this is accompanied by new philosophical underpinnings. I argue that if the philosophical underpinnings of the aid agenda remain the re-colonialization of Africa, it is unlikely that it will be able to resolve the African developmental challenges and would not lead to what Mhone argues should be the grand normative of public sector reforms in Africa, namely inclusive and sustainable human centred development.

One often-ignored part of development aid and the public sector reforms it engendered, which Wohlgemuth noted in his article (though in passing), is the imposition of a number of administrative rules on the public sector. What is clear is that at the same time that the donor community requires the downsizing of the public service, their workload seems to be increasing. Thus, while the state is being incapacitated, the workload of public servants is increasing. This brings to mind another important disincentive through the imposition of widespread rules on the public sector. The rules are such that they make senior servants to spend most of their days completing forms, turning them to compliance officers, and consequently having very little time to engage in strategic thinking and planning. Unable to cope with this onerous task, some senior servants have left the public service. In general, the various aspects of the public sector reforms have not fundamentally altered the performance of the African state. This is evident from the remaining articles in this volume.

Lewis Dzimbiri's article focusses on one component of the public sector reforms, namely performance management system (PMS), with Botswana as a case study. PMS places emphasis on individual contracts and performance. In this system, he argue, the emphasis is on performance, rather than on rules and regulations. Dzimbiri notes that the introduction of the PMS has 
resulted in better service delivery in the country. But, unfortunately, it has also resulted in reform fatigue among public servants, in addition to other challenges that emanated from the public sector reforms in Botswana, just like most other African countries. In fact, across the continent, civil servants are so busy with the (re) introduction (re)implementation of various institutional reforms that very little time is left for formulation and implementation of comprehensive development strategies. Very few countries in the continent have industrial policy strategies that are articulated with agrarian strategies, macro-economic policy and social policy. In addition, the implementation of the PMS in Botswana also highlights one often neglected problem of public sector reforms across the continent, which is that even civil servants entrusted with the implement action of the reforms have no capacity to do so.

A similar point is made by Muriisa in his article on decentralisation in Uganda, where he notes that a major challenge of decentralization is that sub-national governments lack the capacity and personnel to exercise responsibility of service delivery. Unfortunately, the various capacity building initiatives that accompanied the introduction of the public sector reforms have not resolved the capacity crisis, which is coupled with lack of adequate funding. It needs to be noted that the discussion of PMS have to be placed on a broader context, which is the need to build developmental states in Africa. It is generally recognised that weberianness - that is meritocratic recruitments and long-term rewarding careers - are necessary institutional attributes for developmental states, which should be seen as important condition for a human centred development. PMS, with its introduction of short-term performance-based contract, undermines the latter; that is, it erodes the principle of career paths for civil servants and thus hampers the ability of Africa to construct developmental states.

In his article, William Muhumuza focuses on decentralisation in Uganda. He points out that while various reasons may have been advanced for decentralisation, the real motive for decentralization are two convergence interests: namely interests of external donors to, among other things, spread liberal values and marketization; and interests of the African political elite in self preservation and political survival - a similar point made by Omoyefa in his article. In the Uganda case, Muhumuza observes that decentralisation has been motivated, on the one hand, to ensure greater citizens participation and, on the other hand, to enhance the legitimacy of the Museveni regime as a source of political patronage. In general, he argues, decentralisation is adopted as a means of political survival. He also points out that it is important to recognise that decentralization in the continent in the last three decades is part of a neo-liberal agenda, and concludes that it has been implemented without due regards to democracy and democratic principles. 
Muhumuza highlights some of the problems associated with decentralisation in Uganda. These include increased administrative cost, lack of adequate resources for local authorities to meet their developmental needs, political patronage, stifling of fiscal autonomy of local authorities and corruption. Furthermore, like all aspects of the New Public Management and the neoliberal ideology with which it is predicated, the decentralization exercise in Uganda has achieved limited successes because it failed to take local context into consideration; and this is corroborated by Muriisa's argument that "decentralization policy comes from the response to externally determined programmes that differ from local needs". In the light of the above, Muhumuza concludes that decentralisation has not been development enhancing.

Like Muhumuza, Roberts Kabeba Muriisa in his article also focuses on decentralisation in Uganda, which he notes has been intended to improve service delivery and increase citizens participation in the development and governance processes. He argues that, to a large extent, the decentralisation process has been promoted by the World Bank. Muriisa introduces two important concepts, namely: (1) 'freedom to access', which means the freedom of the grassroots to have access to basic services, and (2) 'freedom to decide' which means that after decentralisation, people can decide what they need. Against these conceptual frameworks, he focuses on decentralisation and its impacts on efficiency. In particular, he discusses various ways in which efficiency can be measured or judged. First is allocative efficiency, which basically means that there is a match between local needs and the cost. Second is productive efficiency, meaning the services being provided and the associated costs. The third way to measure efficiency is to see whether the service is cheap and efficient. Fourth, is effectiveness, meaning the extent to which the service provided meets the original goal. Sixth is the question of accountability. Here, one moves from the balance sheet and poses some related questions, namely (a) do the services provided ensure accountability to people, and (b) are the people involved in deciding on how to spend the funds.

Thus, like Muhumuza, Muriisa points to the fact that inadequate funding has been one of the banes of decentralisation. What is clear is that, at a time when local authorities have increasing responsibilities, these have not been matched by increased funding from the national state. This is a context of considerable lack of financial autonomy by the districts, like most local government authorities across the African continent. In a similar vein, downsizing or right-sizing of the public service has been oblivious to increase in demand for services, as Muriisa shows in the case of Uganda where, though primary school enrolment has more than doubled, pupils enrolment has not been matched by increased teacher recruitment. The result is that provision 
and quality of public goods suffer. Using the above as criteria to measure decentralisation in Uganda, Muriisa concludes that though it is a good policy, its implementation has not achieved the desired results. He then proposes measures that need to be taken for decentralization to achieve its desired result of enhanced provisions of service delivery, central to which is improving funding to local councils and establishment of accountability mechanisms.

Honest Prosper Ngowi's article focuses on another component of the public sector reforms, namely privatization. This focus is particularly important because it represents one of the most significant expressions of neo-liberalism to reduce the role of the state in development. In addition to his analysis of privatisation in the Tanzanian context, Ngowi introduces another important concept, which he terms 'agentification' and by which executive agencies are established to undertake a particular function or a particular service delivery task that are considered non-core to the public service. Agentification correlates with what Mkandawire (2007) refers to as institutional monotasking, that is, requiring institutions that could perform multiple development tasks to undertake just one task. This agentification or institutional monotasking, as Ngowi shows in his analysis of the Tanzanian case, has adverse impact on the capacity of the public sector in particular, and the state in general, to provide public goods to citizens. He provides a historical context of the subject matter. According to him, the public sector in Tanzania as from 1967 was responsible for the provision of services to citizens. However, as from the mid-1980s, due to privatisation and agentification, the role of the public sector in service provision has considerably diminished. He notes that 17 areas have been privatised, including estate and building, office, executive, clerical and professional services.

Ngowi highlights some of the challenges of privatisation, which include the infancy of the Tanzanian private sector, which has not enabled it to benefit from the privatisation process; the local private sector's lack of capacity and finance to take advantage of the process; and a lack of understanding by the public of privatisation, and its consequent resistance to it. In the context of the highly informalised infant industry, the main beneficiaries of privatization in Tanzania have been foreign firms. This supports the earlier assertion, by Omoyefa, that the public sector reforms are intended to re-colonise the continent.

Ngowi's article also discusses the agentification of the public sector. This means the use of executive agencies to deliver public services. Presently, there are 20 executive agencies, out of 24 ministries, that undertake a range of public services. But one problem with agentification is the fragmentation of the public sector and, consequently the erosion of the state's capacity. In addition, as Mkandawire correctly observes, agentification leads to institutional 
dualism because these special agencies are better resourced compared to the normal bureaucracy of other state agencies. As a result, not only do officials in the latter have a sense of superiority but, as Ngowi noted, the dichotomy leads to brain-drain from the normal bureaucracy to these agencies. Another problem of the public sector reforms which Ngowi correctly identifies, with respect to agentification in Tanzania (which is also applicable to the privatepublic partnership), is the ability of the state to monitor the performance of the private partner/agent. In the context of low state capacity that has been partly brought about by the reforms, the African state has not been able to ensure that the private agents/partners honour their various agreements. In such a situation, the quality of services and access to them are highly circumscribed. In spite of these shortcomings, the author highlights some positive implications of agentification. In conclusion, he argued that both privatisation and agentification need to be properly managed, and calls for the creation of a better environment to achieve the desired results of privatisation and, in particular, agentification which, he maintains, requires further study.

In his own article on privatization, Kenneth Nyangena uses water and sanitation services in Kenya as a case study. He notes that privatisation was a major policy tool in the 1980s, aimed to improve access to water and sanitation. However, by the 1990s, this goal had not been realised. Subsequently, there was a shift in paradigms, as local authorities began to focus on commercialisation. This implied that they established companies that were run purely on commercial basis, which included the commercialisation of water and sanitation. Nyangena also focuses on the shortcomings and challenges of privatisation in Kenya, namely:

(a) lack of a clear policy for privatisation and the management of water;

(b) lack of proper definition of the roles of different levels of government;

(c) lack of resources;

(d) bad management;

(e) lack of linkages between central government and CSOs in the delivery of water;

(f) lack of stakeholder participation in the management of water and sanitation; and

(g) the concern of autonomous local authorities companies for profits than for social goals, thereby violating the social contract between the state and its citizens.

\section{Conclusion}

The failure of various reforms so far embarked upon in Africa, as highlighted in the various articles in this special issue of Africa Development; and the current global economic crisis, which has considerably discredited the 
paradigm in which the reforms are predicated, calls for a new paradigm and a new approach to public sector reforms. The work of Mhone laid an important foundation for a re-think of public sector reforms and a re-tooling of the state in Africa. As he rightly argues, developmentalism has to be the grand normative of any public sector reform agenda in the continent, and it requires a developmental state, which has to promote both procedural and substantive democracy. This is a good proposition. However, further research is required to tease out the challenge that might arise from the pursuit of a developmentalist agenda in the continent.

Needless to say that the current global economic crisis offers an opportunity for the implementation of a developmentalist goal, without the African state being punished by global markets. In addition, the donor community will have little creditability to dissuade African states from pursuing such a course, given the fact that their own governments have recently become more interventionist. But more importantly, the African people are yearning for developmentalism.

\section{References}

Edigheji, O. (forthcoming) 'Globalisation and Evolving Local Governance in Norway’, Globalizations, Vol. 2, June.

Mhone, G., 2000, 'Enclavity and Constrained Labour Absorptive Capacity in Southern African Economies’, International Labour Office, Southern Africa Multidisciplinary Advisory Team, Discussion Paper No. 12.

Mhone, G., 2003a, 'The Challenges of Governance, Public Sector Reform and Public Administration in Africa' Unpublished, February.

Mhone, G., 2003b, 'Democratisation, Economic Liberalisation and the Quest for Sustainable Development in South Africa', in Guy Mhone and Omano Edigheji, eds., Governance in the New South Africa: The Challenges of Globalisation, Lansdowne: University of Cape Town Press.

Mkandawire, T., 2007, 'Institutional Mono-cropping and Mono-tasking in Africa' Paper presented at the Guy Mhone Memorial Conference on Public Sector Reforms in Africa: Retrospects and Propects, Zomba, Malawi, 22 - 24 August.

Mkandawire, T., 2008, 'From Maladjusted States to Developmental States in Africa', Paper presented at the Conference on The Potentials for and Challenges of Constructing a Democratic Developmental State in South Africa', organized by the Policy Analysis Unit of the Human Sciences Research Council and the Development Bank of Southern Africa, Magaliesburg, Gauteng, South Africa, 4th - 6th June. 